\title{
veterinary Pathological investigations on guillemots (Uria aalge ) stranded on the Belgian coast during the winter of $1993-94$
}

T. Jauniaux, L. Brosens, P. Meire, et al.

Veterinary Record 1998 143: 387-390

doi: 10.1136/vr.143.14.387

Updated information and services can be found at:

http://veterinaryrecord.bmj.com/content/143/14/387

These include:

Email alerting Receive free email alerts when new articles cite this article. Sign up in the service box at the top right corner of the online article.

Notes

To request permissions go to:

http://group.bmj.com/group/rights-licensing/permissions

To order reprints go to:

http://journals.bmj.com/cgi/reprintform

To subscribe to BMJ go to:

http://journals.bmj.com/cgi/ep 
secondly, by the high concentration of various proteins in the muscle exudates compared with the serum samples. The high levels of proteins inhibit the action of the anti-gE serum used in the kit, to a greater extent probably by a process of non-specific saturation. A modification of the detection threshold might not improve the differentiation between muscle exudates and sera. In these conditions, the doubtful results were considered as negative, in order to improve the specificity of the test. When using the threshold for a positive test, recommended by the manufacturer, of 40 per cent inhibition, the individual sensitivity for the detection of anti-gE antibodies in the muscle exudates was on average 93.2 per cent $(95$ per cent confidence interval of 88.8 to 96.9 per cent) and the individual specificity was 98.3 per cent ( 95 per cent confidence interval of 96.5 to 99.5 per cent). These results should allow herds to be followed up satisfactorily by screening animals at the slaughterhouse. This would be possible as the group sensitivity increases rapidly as the number of infected animals tested in an infected herd increases. These values of specificity and sensitivity are slightly higher than those obtained by Nielsen and others (1996) when they were investigating anti-salmonella antibodies. In this study, all the infected herds were detected by using samples of muscle exudate, despite the fact that for some individual animals the test lacked sensitivity.
Muscle exudate samples collected at the slaughterhouse could replace serum samples in the serological follow-up of a prophylactic plan for Aujeszky's disease, provided that the number of samples from each farm were sufficiently large. One factor which remains to be determined, which depends on the prophylactic programme used, is the frequency with which a farm would need to be tested.

Acknowledgements. - The authors would like to thank Dr E. Sellal (LSI) for the gift of the ELISA kits, Dr Y. Leforban for his participation in the preliminary feasibility study and Mr Y. Chauvel (COOPERL) for his help during sampling. This study was financed by the Association Régionale Interprofessionnelle Porcine de Bretagne.

\section{References}

BOUWKAMP, F. T., STEGEMAN, J. A. \& KIMMAN, T. G. (1993) Veterinary Record 134, 327

ELOIT, M., FARGEAUD, D., VANNIER, P. \& TOMA, B. (1989) Veterinary Record 124, 91

NIELSEN, B., BAGGESEN, D. L., LIND, P., FELD, N. \& WINGSTRAND, A. (1996) Proceedings of the 14th IPVS Congress, Bologna, Italy, July 7-10, 1996 STEGEMAN, J. A., TIELEN, M. J. M., KIMMAN, T. G., VAN OIRSCHOT, J. T., HUNNEMAN, W. A. \& BERNDSEN, F. W. (1994) Vaccine 12, 527

\title{
Pathological investigations on guillemots (Uria aalge) stranded on the Belgian coast during the winter of 1993-94
}

\author{
T. Jauniaux, L. Brosens, P. Meire, H. Offringa, F. Coignoul
}

Veterinary Record (1998) 143, 387-390

Pathological investigations were carried out on 67 guillemots (Uria aalge) washed up on the Belgian coast between November 1993 and March 1994. Emaciation and acute haemorrhagic gastroenteropathy were observed in more than 70 per cent of the birds. There was no statistical relationship between the level of oil contamination and the severity of the lesions. Differences in bodyweight were accounted for by age, sex, emaciation, and acute haemorrhagic gastroenteropathy. The birds had a severe weight deficit but the concentrations of pollutants were below acutely toxic levels.

THE southern North Sea is heavily exposed to pollution by oil and by heavy metals and organochlorides which accumulate in marine food webs (North Sea Task Force 1993a, b). As a result, it has been reported that pelagic top predator seabirds can be useful as bioindicators of pollution (Walsh 1990, Stewart and others 1994, Wenzel and Gabrielsen 1995).

In the southern North Sea, guillemots (Uria aalge) are abundant (Camphuysen and Leopold 1994). Since 1915, when the first count of oiled seabirds was conducted in the Netherlands, the guillemot has been a predominant species among birds counted during surveys of beached birds, and since 1980 their numbers have increased significantly (Camphuysen 1989). In addition they are very vulnerable to oil pollution (Camphuysen 1989,

T. Jauniaux, DVM, L. Brosens, MS, F. Coignoul, DVM, PhD, Department of Pathology, Veterinary College, Sart Tilman Bat B43, University of Liege, 4000 Liege, Belgium

P. Meire, MS, PhD, H. Offringa, MS, PhD, Institute of Nature Conservation, Kliniekstraat 25, 1070 Brussels, Belgium
Camphuysen and van Franeker 1992). In the Netherlands, between 1969 and 1985, 89 per cent of guillemot carcases discovered on beaches were oiled (Camphuysen 1989), and between 1986 and 1995, 76 per cent were oiled (Camphuysen 1995). Surveys of beached birds along the Belgian coast revealed that between 1962 and 1977, 97 per cent of guillemots were oiled (Kuijken 1978, Verboven 1979). The fact that they are abundant, pelagic, top predators and vulnerable to oil make guillemots a key species for evaluating the health of North Sea seabirds.

Common findings in stranded seabirds include severe emaciation, acute haemorrhagic gastroenteritis, oil contamination, lack of food and ingestion of plastic materials (von Petermann and others 1989, Camphuysen and van Franeker 1992, Camphuysen and Leopold 1994, Jauniaux and others 1996). However, published information remains fragmentary and related to one type of evaluation. To investigate more adequately the potential causes of death of these guillemots, a research team involving ornithologists, toxicologists, and veterinary pathologists has evaluated the causes of death of stranded wintering seabirds, and particularly of guillemots stranded along the Belgian coast. This paper describes the lesions observed in guillemots stranded during the winter of 19931994, and discusses the potential causes of mortality.

\section{Materials and methods}

Collection of birds

Between November 1993 and March 1994, Belgian beaches were systematically surveyed and biometric measurements were made on birds collected (Offringa and others 1995). Putrefied carcases were discarded, and other birds were individually labelled and kept frozen until examined. 
TABLE 1: Statistical analyses of biological and pathological data from 50 guillemots stranded on the Belgian coast during the winter of 19931994

\begin{tabular}{|c|c|c|c|c|c|c|c|}
\hline & & \multicolumn{2}{|c|}{ Cachexia } & \multicolumn{2}{|c|}{ Oil } & \multicolumn{2}{|c|}{$\begin{array}{l}\text { Acute haemormagic } \\
\text { gastroenteropathy }\end{array}$} \\
\hline & & Present & Absent & Present & Absent & Present & Absent \\
\hline \multirow[t]{2}{*}{ Age } & $\begin{array}{r}<1 \\
\text { Adult }\end{array}$ & $\begin{array}{l}28 \\
12\end{array}$ & $\begin{array}{l}7 \\
3\end{array}$ & $\begin{array}{c}12 \\
7\end{array}$ & $\begin{array}{c}23 \\
8\end{array}$ & $\begin{array}{l}29 \\
15\end{array}$ & $\begin{array}{l}6 \\
0\end{array}$ \\
\hline & & \multicolumn{2}{|c|}{ NS } & \multicolumn{2}{|c|}{ NS } & \multicolumn{2}{|c|}{ NS } \\
\hline \multirow[t]{2}{*}{ Sex } & $\begin{array}{c}M \\
F\end{array}$ & $\begin{array}{l}18 \\
22\end{array}$ & $\begin{array}{l}9 \\
1\end{array}$ & $\begin{array}{c}14 \\
5\end{array}$ & $\begin{array}{l}13 \\
18\end{array}$ & $\begin{array}{l}23 \\
21\end{array}$ & $\begin{array}{l}4 \\
2\end{array}$ \\
\hline & & \multicolumn{2}{|c|}{$P<0.05$} & \multicolumn{2}{|c|}{ NS } & \multicolumn{2}{|c|}{ NS } \\
\hline
\end{tabular}

NS Not significant at $\mathrm{P}<0.05$

$<1$ Juvenile

\section{Necropsy procedure}

Sixty-seven guillemots were necropsied, using a consistent protocol (Dorrestein and van der Hage 1993, Jauniaux and others 1996). They were weighed, and oil contamination on the plumage and/or in the intestinal tract and any lesions were recorded. A 'cachexia scale' from 0 to 3 was used to evaluate emaciation: 0 ) non-cachectic, 1) absence of subcutaneous and abdominal fat, light atrophy of pectoral muscles, 2) absence of subcutaneous and abdominal fat, moderate atrophy of pectoral muscles, 3) absence of subcutaneous and abdominal fat, severe atrophy of pectoral muscles. The birds were sexed by an examination of the gonads and their age was determined by the presence (juvenile) or the absence (adult) of the bursa of Fabricius. Tissues were collected and processed for histopathological, bacteriological and parasitological examinations as described by Jauniaux and Coignoul (1994), Brosens and others (1996) and Jauniaux and others (1996). Pectoral muscles, liver and kidneys were sampled for toxicology.

\section{Statistical analysis}

Preliminary $\chi^{2}$ tests using $2 \times 2$ contingency tables were made to investigate associations between the biological data (age and sex) and the pathological findings (Jauniaux and others 1996). The associations were also analysed using Mann-Whitney $U$ tests and differences were considered as significant for $P<0.05$. Only 50 guillemots whose age and sex were determined were used. Owing to the small sample size, the cachectic categories 1,2 and 3 were pooled for both the statistical analyses and interpretation of the data.

\section{Results}

\section{Birds collected}

Strandings of guillemots occurred throughout the winter. A peak density of strandings was observed during February $(0.88$ guillemot $/ \mathrm{km}$ of surveyed beach), 45 per cent being fouled with oil during the month. Biometric measurements indicated that most of the guillemots belonged to the nominate southern race $U$ aalge albionis, breeding in Ireland, Heligoland and southern Britain, and $U$ aalge aalge, the northern race, breeding in northern Scotland (Offringa and others 1995).

TABLE 3: Variations in bodyweight in relation to sex, cachexia and intestinal lesions in $\mathbf{5 0}$ guillemots stranded on the Belgian coast during the winter of 1993-1994

\begin{tabular}{lrl}
\hline \multicolumn{1}{c}{ Parameter } & Mean (sd) bodyweight $(\mathrm{g})$ \\
\hline Sex & Females: & $646(75)$ \\
Machexia & Males: & $714(118)$ \\
& Normal birds: & $736(92)$ \\
Acute haemorrhagic & Birds with lesions: & $661(102)$ \\
gastroenteropathy & Normal birds: & $780(112)$ \\
\hline
\end{tabular}

TABLE 2: Statistical analyses of the relationships between acute haemorrhagic gastroenteropathy, cachexia and oil contamination on $\mathbf{5 0}$ orrhagic gastroenteropathy, cachexia and oil contamination on 50
guillemots stranded on the Belgian coast during the winter of 1993-1994

\begin{tabular}{|c|c|c|c|c|c|}
\hline & & \multicolumn{2}{|c|}{$\begin{array}{l}\text { Acute haemorrhagic } \\
\text { gastroenteropathy }\end{array}$} & \multicolumn{2}{|c|}{ Cachexia } \\
\hline & & Present & Absent & Present & Absent \\
\hline \multirow[t]{2}{*}{ Oil } & $\begin{array}{l}\text { Present } \\
\text { Absent }\end{array}$ & $\begin{array}{l}17 \\
27\end{array}$ & $\begin{array}{l}2 \\
4\end{array}$ & $\begin{array}{l}13 \\
27\end{array}$ & $\begin{array}{l}6 \\
4\end{array}$ \\
\hline & & \multicolumn{2}{|c|}{ NS } & \multicolumn{2}{|c|}{ NS } \\
\hline Cachexia & $\begin{array}{r}\text { Present } \\
\text { Absent }\end{array}$ & $\begin{array}{l}37 \\
7\end{array}$ & $\begin{array}{l}3 \\
3\end{array}$ & & \\
\hline
\end{tabular}

NS Not significant at $P<0.05$

\section{Necropsies}

There were 34 males and 26 females. The sex could not be determined precisely in seven birds that were more putrefied than expected, but had not been discarded initially. Thirty-five were immature, 15 were adult and the age of 17 birds could not be determined precisely for the same reason. The mean (sd) weights were 736 (92) g for 19 non-cachectic birds, and 661 (102) g for 48 cachectic birds. The minimum and maximum weights were $440 \mathrm{~g}$ and $980 \mathrm{~g}$.

The most frequent observations were acute haemorrhagic gastroenteropathy ( 75 per cent), cachexia ( 72 per cent) and oil contamination ( 36 per cent). The gastrointestinal tract was empty in 91 per cent of the birds. In cases of acute haemorrhagic gastroenteropathy, the serosal surface of the intestine was congested, the intestinal wall was thickened and hyperaemic, and the contents of the lumen were haemorrhagic. Other lesions were acute gastric ulcers (nine cases), urate nephropathies (seven cases) and intestinal haemorrhages (three cases). Two birds had fungal pneumonitis and airsacculitis characterised by greenish white nodules and plaques in the air sacs and in the lungs. Aspergillus fumigatus was isolated from both birds. Nematodes were found in the proventriculus in 12 cases and under the koilin layer of the gizzard in 17 cases. The most common worm species were Contracaecum spiculigerum, Cosmocephalus obvelatus and Paracuaria tridentata. Pentastomids were observed in the air sacs of two birds.

Statistical tests were applied to the data from the 50 guillemots for which all the data were available (Tables. 1 and 2). There was no significant association between age and the observations of cachexia, acute haemorrhagic gastroenteropathy and oil contamination. Female birds were more often cachectic than male birds. In addition, the lesions of cachexia and acute haemorrhagic gastroenteropathy were not significantly associated either with each other or with oil contamination. Mann-Whitney U tests (Table 3) revealed that there were significant differences in bodyweight due to sex $(\mathrm{P}<0.05)$, cachexia $(\mathrm{P}<0.01)$ and acute haemorrhagic gastroenteropathy $(\mathrm{P}<0 \cdot 05)$.

\section{Discussion}

By far the most frequent and most significant lesions observed were cachexia and haemorrhagic enteropathy. Bodyweight (Tables 3 and 4), was too low in all the birds, with a deficit of 35 per cent for cachectic birds and 25 per cent for so-called normal

TABLE 4: Mean (sd) bodyweights (g) of guillemots stranded on the Belgian coast during the winter of 1993-1994 and on the Dutch coast (Camphuysen 1989) and shot at sea in Scotland in November (Furness and others 1994)

\begin{tabular}{|c|c|c|c|c|}
\hline \multicolumn{2}{|c|}{ Age and sex } & \multirow{2}{*}{$\begin{array}{c}\text { Belgian coast } \\
753(131) \\
683(69)\end{array}$} & \multirow{2}{*}{$\begin{array}{c}\text { Dutch coast } \\
718(70) \\
706(47)\end{array}$} & \multirow{2}{*}{$\begin{array}{c}\text { Scotland } \\
1031\end{array}$} \\
\hline Adult & $\begin{array}{r}\text { Male } \\
\text { Female }\end{array}$ & & & \\
\hline Juvenile & $\begin{array}{r}\text { Male } \\
\text { Female }\end{array}$ & $\begin{array}{c}703(115) \\
623(71)\end{array}$ & $\begin{array}{l}724(93) \\
674(93)\end{array}$ & \\
\hline
\end{tabular}


birds, when compared with a population of guillemot shot at sea in Scotland in November (Furness and others 1994). It is remarkable that 91 per cent of the birds had empty digestive tracts, indicating either that food was unavailable, or that the birds were unable to feed. As a result, the wintering guillemots stranded along the Belgian coast were all debilitated, with empty guts and weight deficits of variable severity. Similar observations applied to guillemots stranded along the Dutch coast, when the weight range (Camphuysen 1989) was compared with birds from Scotland (Table 4). The cause of the emaciation was not determined, but it could have been due to an association of several factors that often occur in the wild, including food deprivation, mild chronic exposure to oil, low temperature and the long-term effect of contaminants leading to rapid starvation (Bray 1979). Gulls which were deprived experimentally of food and exposed to a single oral dose of oil lost 25 per cent of their weight in four days (Peakall and others 1985), and after being oiled, guillemots lost 33 per cent of their bodyweight during rehabilitation in a refuge (Khan and Ryan 1991). In the latter group, the weight loss was associated with malabsorption, impaired liver function and increased metabolic rates.

Acute haemorrhagic gastroenteropathy and intestinal haemorrhages have been reported to be linked with exposure to oil in the field (Fry and Lowenstine 1985, Pionneau 1987) but the conditions have not been reproduced experimentally (Holmes and others 1978, Szaro and others 1978, Holmes and others 1979, Leighton 1985, 1986). The lesions could have been due more to the result of stress than to a direct toxic effect of oil ingestion (Leighton 1993). The consumption of petroleum-contaminated food appears to be a non-specific stressor, increasing the effects of other stresses such as low temperature (Holmes and others 1978, 1979).

It was surprising that there was no correlation between the lesions of cachexia and haemorrhagic enteropathy and the presence of oil on the plumage or in the gut. These data do not agree with previous field observations (Jauniaux and others 1994, 1996) or with experimental work (Peakall and others 1985). However, a negative correlation has been reported between nutritional state and severity of oil foulage, birds severely contaminated with oil exposure being in a good nutritional state, and those less severely contaminated being emaciated (Camphuysen 1989, Camphuysen and van Franeker 1992, Camphuysen and Leopold 1994). The apparent lack of a correlation between recent oil exposure and the lesions could have several explanations. Because oil is a pervasive pollutant of the southern North Sea, mild, chronic exposure, not necessarily visible on the feathers or in the gut, could lead to chronic debilitating effects, such as cachexia, that might be readily linked to a precise cause. In addition, it is suspected that some of the guillemots had stayed previously in rehabilitation centres. Among the necropsied birds, two had respiratory aspergillosis, a disease that occurs when a bird's resistance is impaired (Chute and Richard 1991, Jauniaux and Coignoul 1994). Immunosuppression induced by the stress of captivity, and the lack of natural exposure of marine birds to fungal pathogens in the wild, may predispose these species to the infection (Dorrestein and van der Hage 1997). Oiled birds that had been cleaned in rehabilitation centres and then released may have died without any sign of oil contamination. As suggested by Thomas and others (1997), all released birds should be ringed.

There may be several reasons for the relatively low percentage of oiled guillemots on the Belgian coast in the winter of 19931994. First, as previously suggested, a considerable number of birds may have been cleaned in rehabilitation centres, released, and then died. Secondly, wide annual variations in the percentage of oiled carcases among stranded birds have been observed along the Dutch coast, perhaps in relation to similar variations in the amounts of oil released at sea in the same period (Camphuysen 1995).

As was also found by Brosens and others (1996), the guillemots from the Belgian coast were only weakly parasitised, and the parasites were not regarded as the primary cause of death.

The concentrations of heavy metals, organochlorides, and total and organic mercury have been previously reported for the tissues

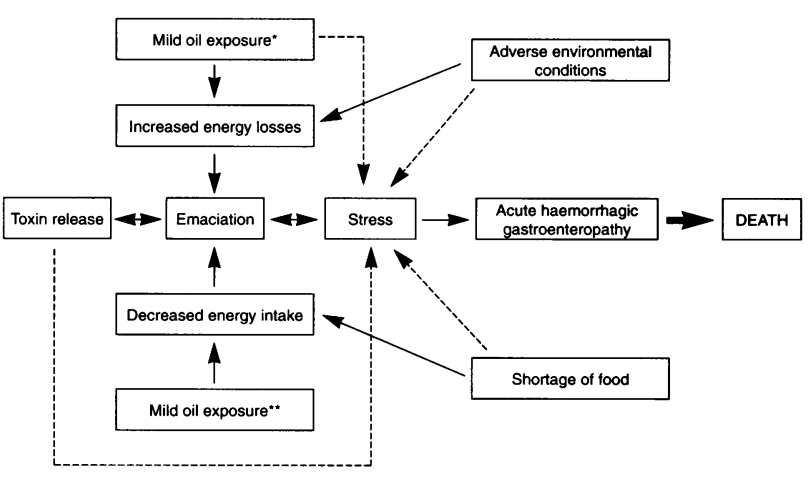

FIG 1: Proposed mechanism to explain the death of wintering guillemots stranded along the Belgian coast during the winter of 1993-1994. --- stressful associations leading to rapid starvation, * loss of buoyancy and insulation leading to increased metabolic rate, ** intestinal malabsorption leading to impaired metabolic rate

of guillemots from the Belgian coast by Debacker and others (1997). They concluded that for each lesion observed (cachexia, acute haemorrhagic gastroenteropathy), there were differences in the tissue concentrations of these pollutants indicating a correlation between the lesions and the levels of toxins. In addition, metal concentrations were below acutely toxic levels (Nicholson and others 1983, Nicholson and Osborn 1983, Wenzel and Gabrielsen 1995) and none of them could be blamed as a direct cause of death. An alternative hypothesis might therefore be that the lesions were themselves the cause of the differences in the concentrations of toxins in tissues, rather than that the contaminants were responsible for the lesions. It is therefore possible that, as proposed by Osborn (cited in Walsh 1990), variations in the fat and protein contents or enzyme activities of the tissues were responsible for the changes in the concentrations of pollutants. Such variations in fat or protein occur as a bird becomes emaciated, and lead to the progressive release of toxins from tissues during weight loss and fat consumption. As suggested by Debacker and others (1997) the release of toxins as a bird becomes emaciated may represent additional debilitating stress factors. In addition to the variations in geographical origin, age, physiology and season that have been claimed to be responsible for the intraspecific variations observed in levels of pollutants in tissues (Walsh 1990, Stewart and others 1994, Wenzel and Gabrielsen 1995), health status, and specific lesions should be taken into account in toxicological studies.

It is concluded that the death of wintering guillemots stranded along the Belgian coast can be explained by the following mechanism (Fig 1). The stresses of food deprivation, mild oil exposure or the long-term effect of contaminants may have led to the birds' debilitation. The concentrations of pollutants were below those considered to be acutely toxic, but they may have constituted an additional stress in the debilitation process. The use of stranded guillemots to monitor pollutants in the North Sea should take into account the necropsy results and the severe debilitation of the birds.

Acknowledgements. - The authors thank Mr W. van den Bossche and $\mathrm{Mr}$ J. Tavernier for collecting and providing seabirds from the beaches. Thanks are also due to Mr Bouquegneau and Mr Joiris for useful comments on the manuscript. The authors also acknowledge $\mathrm{Mr} \mathrm{H}$. Gianfreda, Mr R. Nef and Mr R. van Denhoven for technical assistance. This research was supported by the Impulse Programme in Marine Sciences (Belgian State), Prime Minister's Services, Office for Scientific, Technical and Cultural Affairs (grant MS/12/033) and by the European Community (NORSPA 90-1/B/002).

\section{References}

BRAY, G. A. (1979) Pathologic physiology. Eds W. A. Sodeman, T. M. Sodeman. 6th edn. Philadelphia, Saunders Company. p 971

BROSENS, L., JAUNIAUX, T., SIEBERT, U., BENKE, H. \& COIGNOUL, F. (1996) Veterinary Record 139, 254 
CAMPHUYSEN, C. J. (1989) Beached bird surveys in the Netherlands 1915/1988. Seabird mortality in the southern North Sea since the early days of oil pollution. Amsterdam, Werkgroep Noordzee

CAMPHUYSEN, C. J. (1995) Sula 9, 1

CAMPHUYSEN, C. J. \& LEOPOLD, M. F. (1994) Atlas of seabirds in the southern North Sea. Texel. p 1

CAMPHUYSEN, C. J. \& VAN FRANEKER, J. A. (1992) The value of beached bird surveys in monitoring marine oil pollution. Zeist, Vogelsbescherming Nederlands

CHUTE, H. L. \& RICHARD, J. L. (1991) Diseases of poultry. Ed B. W. Calnek. 9th edn. Ames, Iowa State University Press

DEBACKER, V., HOLSBEEK, L., TAPIA, G., GOBERT, S., JOIRIS, C., JAUNIAUX, T., COIGNOUL, F. \& BOUQUEGNEAU, J. M. (1997) Diseases of Aquatic Organisms 29, 159

DORRESTEIN, G. M. \& VAN DER HAGE, M. H. (1993) Proceedings of the European Conference of Avian Medicine and Surgery, Utrecht

DORRESTEIN, G. M. \& VAN DER HAGE, M. H. (1997) Marine mammals, seabirds, and pollution of marine systems. Eds T. Jauniaux, J.-M. Bouquegneau, F. Coignoul, Liège, Presses de la Faculté de Médecine Vétérinaire. p 151

FRY, M. D. \& LOWENSTINE, L. J. (1985) Archives of Environmental Contamination and Toxicology 14, 725

FURNESS, R. W., THOMPSON, D. R. \& HARRISON, N. (1994) Seabird 16, 22

HOLMES, W. N., CRONSHAW, J. \& GORSLINE, J. (1978) Environmental Research 17, 177

HOLMES, W. N., GORSLINE, J. \& CRONSHAW, J. (1979) Environmental Research 20, 425

JAUNIAUX, T., BROSENS, L. \& COIGNOUL, F. (1994) Proceedings of scientific symposium on the 1993 North Sea Quality Status Report, North Sea Task Force. p 317 (Abstract)

JAUNIAUX, T. \& COIGNOUL, F. (1994) Annales de Médecine Vétérinaire 4, 59

JAUNIAUX, T., BROSENS, L., FARNIR, F., MANTECA, C., LOSSON, B., TAVERNIER, J., VINDEVOGEL, H. \& COIGNOUL, F. (1996) Annales de Médecine Vétérinaire 140, 149
KHAN, R. A. \& RYAN, P. (1991) Bulletin of Environmental Contamination and Toxicology 46, 216

KUIJKEN, E. (1978) Ibis 120, 122

LEIGHTON, F. A. (1985) Veterinary Pathology 22, 393

LEIGHTON, F. A. (1986) Veterinary Pathology 23, 254

LEIGHTON, F. A. (1993) Environmental Revue 1, 92

NICHOLSON, J. K., KENDALL, M. D. \& OSBORN, D. (1983) Nature 304, 633

NICHOLSON, J. K. \& OSBORN, D. (1983) Journal of Zoology 200, 99

NORTH SEA TASK FORCE, (1993a) North Sea Quality Status Report 1993. London, Oslo and Paris Commissions. p 34

NORTH SEA TASK FORCE, (1993b) North Sea Quality Status Report 1993. London, Oslo and Paris Commissions, p 80

OFFRINGA, H., MEIRE, P. \& VAN DEN BOSSCHE, W. (1995) Tellingen van gestrande zeevogels langs de Vlaamse kust, november 1993-maart 1994, Rapport IN 95.5. Hasselt, Rapport IN 95.5 Institute of Nature Conservation

PEAKALL, D. B., JEFFREY, D. A. \& MILLER, D. S. (1985) Ambio 14, 108

PIONNEAU, F. (1987) Le Point Vétérinaire 19, 469

STEWART, F. M., THOMPSON, D. R., FURNESS, R. W. \& HARRISON, N. (1994) Archives of Environmental Contamination and Toxicology 27, 168

SZARO, R. C., DIETER, M. P. \& HEINZ, G. H. (1978) Environmental Research 17, 426

THOMAS, T M. ROBINSON, I. \& SEDDON, C. (1997) Marine mammals, seabirds, and pollution of marine systems. Eds T. Jauniaux, J.-M. Bouquegneau, F. Coignoul, Liège, Presses de la Faculté de Médecine Vétérinaire. p 175

VERBOVEN, J. (1979) Tellingen van stookolieslachtofferrs en andere dode vogels langs de Belgische kust. Rijkuniversiteit van Gent. Faculteit der Wetenschappen, laboratorium voor oecologie der dieren. Zoogeografte en Natuurbehoud

VON PETERMANN, S., GLÜNDER, G., HEFFELS-REDMANN, U. \& HINZ, K.H. (1989) Deutsche Tierarztliche Wochenschrift 96, 271

WALSH, P. (1990) Heavy metals in the marine environment. Eds R. W. Furness, P. S. Rainbow. Boca Raton, CRC Press. p 183

WENZEL, C. \& GABRIELSEN, G. W. (1995) Archives of Environmental Contamination and Toxicology 29, 198

\title{
Comparison of polyclonal, monoclonal and protein $\mathrm{G}$ peroxidase conjugates in an enzyme-linked immunosorbent assay for the diagnosis of Brucella ovis in sheep
}

\author{
C. M. Marín, B. Alonso-Urmeneta, I. Moriyón, S. Pérez-Gómez, J. M. Blasco
}

Veterinary Record (1998) 143, 390-394

\begin{abstract}
The sensitivities of three commercial peroxidase conjugates (polyclonal anti-sheep IgG, recombinant protein $G$ and a monoclonal anti-ruminant $\mathbf{I g G}_{1}$ ) in an enzyme-linked immunosorbent assay for Brucella ovis were evaluated. The monoclonal and protein $G$ conjugates reduced, but did not totally remove, the characteristic background reactivity observed with the sera from brucella-free sheep. The protein G conjugate provided the best sensitivity, similar to that obtained with the classical gel diffusion test. Both tests were highly specific when testing sera from brucella-free animals but detected as positive a large proportion of sera from both Brucella melitensis-infected and $B$ melitensis Rev 1-vaccinated sheep.
\end{abstract}

Brucella ovis induces an infectious disease in sheep which is characterised by genital lesions in rams, and by placentitis and abortions in ewes. Simple direct diagnostic tests are lacking and the

C. M. Marín, DVM, PhD, J. M. Blasco, DVM, PhD, Unidad de Sanidad Animal, Servicio de Investigación, Agroalimentaria, Diputación General de Aragón, Ap 727, 50080 Zaragoza, Spain

B. Alonso-Urmeneta, $\mathrm{PhD}$, I. Moriyón, $\mathrm{PhD}$, Departamento Microbiología, Universidad de Navarra, Ap 177, 30080, Pamplona, Spain

S. Pérez-Gómez, DVM, Laboratorio Pecuario, Gobierno de Navarra, Serapio Huici s.n., 31610, Villaba, Spain disease is diagnosed in eradication programmes by means of serological tests, particularly the complement fixation (CF) test and the gel diffusion (GD) test (Blasco 1990). Several indirect enzymelinked immunosorbent assays (ELISAs) have been tested during the last decade and reported to be equally or slightly more sensitive than the CF and GD tests (Worthington and others 1984, Marín and others 1989). However, none of the ELISAs has been found to be completely satisfactory for the diagnosis of $B$ ovis infection. The main factors affecting both the sensitivity and specificity of the ELISAs for $B$ ovis are the antigen (Chin 1983, Worthington and others 1984, Marín and others 1989, Ficapal and others 1995), the substrate (Marín and others 1989) and the conjugate (Ficapal and others 1995). It is known that the hot saline extract from $B$ ovis is currently the best antigen (Worthington and others 1984, Marín and others 1989, Ficapal and others 1995), and this extract has been shown to contain both the rough lipopolysaccharide and main proteins of the outer membrane of $B$ ovis (Riezu-Boj and others 1986, 1990). However, little information is available on the diagnostic efficacy of the different conjugates available (Ficapal and others 1995). The anti-bovine polyclonal conjugate of IgG heavy and light chain specificity can be used in an ELISA to detect ovine antibodies to $B$ ovis (Worthington and others 1984). This test improved the sensitivity of both the CF and GD tests but was unable to discriminate completely between sera from infected and brucella-free rams (Worthington and others 1984) owing to the high background reactivity of the latter. This problem is not solved by the use of polyclonal anti-ovine conjugates of IgG heavy and light chain specificity (Riezu-Boj and others 1986, 